\title{
Physical and Chemical Properties of Crystalline Acetylesterase from Sclerotinia Fungus
}

\author{
Susumu OI \\ Faculty of Science, Osaka City University \\ Received October 24, 1973
}

\begin{abstract}
The molecular weight of crystalline acetylesterase (AcE) from Sclerotinia libertiana was determined to be 78,500 by both Archibald and gel filtration methods. The sedimentation coefficient, $s_{20, w}$, was determined to be $5.05 \mathrm{~S}$. The amino acids and carbohydrate composition of AcE was determined as follows: Lys His $_{14}$ Arg $_{18}$ Asp $_{76}$ Thr $_{52}$ Ser $_{62}$ Glu $_{60}$ Pro $_{48}$ Gly $_{90}$ Ala $_{57}$

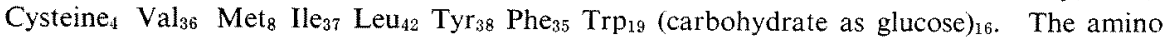
and carboxyl terminals of AcE were found to be threonine and serine, respectively. Isoelectric focusing electrophoresis with carrier ampholite revealed that AcE has an isoelectric point at around 3.95. Optical rotatory dispersion measurements showed that $[a]_{\mathrm{D}}, a_{0}, b_{0}$ and $\lambda_{0}$ were $-22,-110,-75$ and $234.5 \mathrm{~nm}$, respectively, suggesting that the enzyme contains $11 \%$ of the $a$-helix structure.
\end{abstract}

In a previous paper, we reported the purification method and some enzymatic properties of acetylesterase (AcE, EC 3.1.1.6) of Sclerotinia libertiana FCL. ${ }^{1}$ ' The structural features of the esteratic site of $\mathrm{AcE}$ were suggested by the inhibition observed by certain kinds of polybasic organic acids as well as by the mechanism of action on the substrate having one or two ester-bonds in a molecule.

In the present paper, the physical and chemical properties of the crystalline AcE of Sclerotinia libertiana FCL were investigated.

\section{MATERIALS AND METHODS}

Enzyme. AcE of Sclerotinia fungus was purified by the method described previously, ${ }^{1 /}$ and the homogeneity of purified ACE was confirmed by electrophoresis, ultracentrifugation and chromatography on CM cellulose column. The specific activity was 2380 units per mg protein. The enzyme concentration was determined spectrophotometrically, assuming that the $E_{1 \mathrm{c} \text { m }}^{1 \%}$ at $280 \mathrm{~nm}$ was 23.24. AcE activity was assayed according to the method described previously. ${ }^{\mathrm{t}}$

Ultracentrifuge runs. Sedimentation velocities were measured with a Hitachi model UCA-1 ultracentrifuge operating at $54,400 \mathrm{rpm}$. The sedimentation coefficient was calculated as described by Schachman ${ }^{21}$ and corrected to $20^{\circ} \mathrm{C}$ in water according to the method described by Svedberg."
Gel filtration. The molecular weight of $\mathrm{AcE}$ was estimated by Sephadex G-200 column chromatography according to Andrew's method. ${ }^{4}$ The elution volume $\left(V_{e}\right)$ was calibrated for estimating the molecular weight of proteins using proteins of known molecular weights as standards.

Isoelectric focusing electrophoresis. The carrier ampholytes (LKB-Produkter AB) used in this investigation were selected to give a $\mathrm{pH}$ gradient between $\mathrm{pH} 3$ and 10. Focusing of the protein was carried out at $4^{\circ} \mathrm{C}$ in a special vertical electrolysis column of $110 \mathrm{ml}$ capacity, equipped with a cooling jacket (LKBProdukter $\mathrm{AB}$ ). Measurements of $\mathrm{pH}$ were made with a Hitachi model $\mathrm{M}-5 \mathrm{pH}$ meter.

Determination of amino acid composition. Ten milligrams of freeze-dried enzyme were hydrolyzed with $6 \mathrm{~N}$ hydrochloric acid in evacuated, sealed tubes at $110^{\circ} \mathrm{C}$ for $18,24,48$ and $72 \mathrm{hr}$. In all cases small amounts of humins were formed during the hydrolysis. The hydrolysates were evaporated to dryness in vacuo to remove $\mathrm{HCl}$ and subjected to amino acid analysis by a Hitachi Amino Acid Autoanalyzer KLA-2. Values for serine and threonine were obtained by extrapolation to zero time, and maximum values were taken for isoleucine and arginine. The average of four periods of hydrolysis were used for the remainder of the amino acids. For the determination of tryptophan and tyrosine contents, the enzyme was dissolved in $1 / 10 \mathrm{~N}$ sodium hydroxide to the concentration of $5 \times 10^{-5} \mathrm{M}$. The optical density of the enzyme solution was determined at $280,294.4,330$ and $360 \mathrm{~nm}$. The concentrations of tryptophan plus tyrosine were determined by 
the routine method described by Goodwin and Morton. ${ }^{53}$ The sulfhydryl groups were titrated spectrophotometrically with PCMB according to a modification of Boyer's method. ${ }^{6}$ Half-cystine and methionine were determined as cysteic acid and methionine sulfone, respectively, after oxidation of the enzyme with performic acid as described by Hirs. ${ }^{* 1}$

Detection of carbohydrate. The amounts of carbohydrate in AcE protein were determined by the phenolsulfuric acid ${ }^{8}$ and anthrone methods.91 For the calculation, a standard curve was prepared with D-glucose.

\section{$N$-terminal amino acid analysis}

a. Dinitrophenyl method. The procedure of Fraenkel-Conrat, Harris and Levy ${ }^{10 !}$ was used for $\mathrm{N}$ terminal amino acid.

b. Detection by aminopeptidase. AcE protein was incubated with aminopeptidase of Bacillus subtilis under the conditions described by Minamiura et al. ${ }^{11}$ At certain time intervals, $10-\mu 1$ aliquots of the reaction mixture were taken and spotted on a filter paper. In order to stop the enzyme reaction, the spotted area was immediately acidified with a trace amount of $2.0 \mathrm{M}$ acetic acid and dried in an air current. Paper chromatography was done using Toyo Roshi No. 50 paper with butanol: acetic acid: water $(4: 1: 2)$ and butanol: pyridine: water $(1: 1: 1)$ as developing solvents. The color density developed with ninhydrin was read on a densitometer, Toyo Densitorol DMU-2, and from the value, the quantity of amino acid was calculated by correcting with a factor obtained from paper chromatography with known quantities of amino acids.

\section{C-terminal amino acid analysis}

a. Detection by carboxypeptidase A. AcE protein was incubated with carboxypeptidase $\mathrm{A}$ of bovine pancreas purchased from Seikagaku Kogyo Co, according to the method described by Fraenkel-Conrat, Harris and Levy. ${ }^{10}$ At certain time intervals, $10-\mu 1$ aliquots of the reaction mixture were taken and immediately acidified with a trace amount of $2.0 \mathrm{M}$ acetic acid in order to stop the enzyme reaction. After being dried under $\mathrm{N}_{2}$ gas flow, the residue was dissolved in a very small amount of buffer and subjected to analysis of C-terminal amino acid in a Hitachi Amino Acid Autoanalyzer KLA-2.

b. Detection by carboxypeptidase $Y$. AcE protein $(3.5 \mathrm{mg}$ ) was dissolved in $20 \mu \mathrm{l}$ of $0.1 \mathrm{~m}$ pyridine-acetate buffer, pH 5.5, and digested at $25^{\circ} \mathrm{C}$ by carboxypeptidase $Y .{ }^{12}$ The carboxypeptidase $Y$ used was a sample supplied through the courtesy of Dr. Heinrickson, Department of Biochemistry, the University of Chicago. The weight ratio of AcE protein to carboxypeptidase $Y$ was 250 . Hydrolysis was stopped by adding $2.0 \mathrm{M}$ acetic acid at appropriate time intervals. The pyridine acetate buffer was removed in $\mathrm{N}_{2}$ gas flow, then the samples were dissolved in $\mathrm{pH} 2.2$ buffer and applied to an amino acid analyzer, Durrum D-500, after removal of insoluble material by centrifugation (range 1 to 10 nmoles per amino acid).

Measurement of optical rotatory dispersion (ORD), ORD measurement was done with a Jasco spectropolarimeter model ORD/UV-5 at the Osaka Municipal Technical Research Institute. The resulting data were interpreted by means of equation (1) of Moffitt-Yang. ${ }^{13}$

$$
\left[m^{\prime}\right]=\frac{a_{0} \lambda_{0}^{2}}{\lambda^{2}-\lambda_{0}^{2}}+\frac{b_{0} \lambda_{0}^{4}}{\left(\lambda^{2}-\lambda_{0}^{2}\right)^{2}}
$$

The parameters, $a_{0}$ and $b_{0}$, were evaluated from the intercept and slope, respectively, of a plot of $\left[m^{\prime}\right]_{\lambda} \frac{\lambda^{2}-\lambda_{0}{ }^{2}}{\lambda_{0}{ }^{2}}$ yersus $\frac{\lambda_{0}{ }^{2}}{\lambda^{2}-\lambda_{0}{ }^{2}}$ where $212 \mathrm{~nm}$ was adopted as $\lambda_{0}$. The dispersion constant, $\lambda_{\mathrm{e}}$, in equation (2)

$$
\lambda^{2}[\alpha]_{\lambda}=\lambda_{c}^{2}[\alpha]_{\lambda}+\mathrm{A}
$$

was calculated from the slope of the Yang plot, $\lambda^{2}[\alpha] \lambda$ versus $[\alpha]_{\lambda}$. ORD data in the ultraviolet region were measured with $0.4 \sim 1.0 \%$ of protein concentrations using cells of $0.1 \mathrm{~mm}$ path length and expressed in terms of $\left[m^{\prime}\right]$, the reduced mean residue rotation, defined as

$$
\left[m^{\prime}\right]=\frac{3}{\left(n^{2}+2\right)} \frac{m_{0}}{100}[\alpha]_{\lambda}
$$

where $[\alpha]_{\lambda}$ is the specific rotation at wavelength $\lambda, M_{0}$ is the average residue weight (assumed to be 112), and $n$ is the refractive index of the solvent at wavelength $\lambda$. The refractive indices as a function of wavelength were obtained from the table of Fasman. ORD measurements in the visible region were made from 300 to $600 \mathrm{~nm}$ using a cell of $0.5 \mathrm{~cm}$ path length. The protein concentration used was $0.78 \%$.

\section{RESULTS AND DISCUSSION}

\section{Crystallization of AcE}

Acetone was cautiously added to the purified enzyme solution $(1.5 \mathrm{ml})$ containing $1 / 200 \mathrm{M}$ calcium acetate until a faint turbidity appeared at $\mathrm{pH} \mathrm{6.0,} \mathrm{and} \mathrm{the} \mathrm{amorphous} \mathrm{precipitate} \mathrm{was}$ removed by centrifugation. The enzyme crystallized from the supernatant solution when it was allowed to stand overnight at $4^{\circ} \mathrm{C}$. Figure 1 shows a microphotograph of crystalline AcE of Sclerotinia fungus which shaped triangle. The specific activity of the crystalline enzyme was 2380 , and activity recovery was 


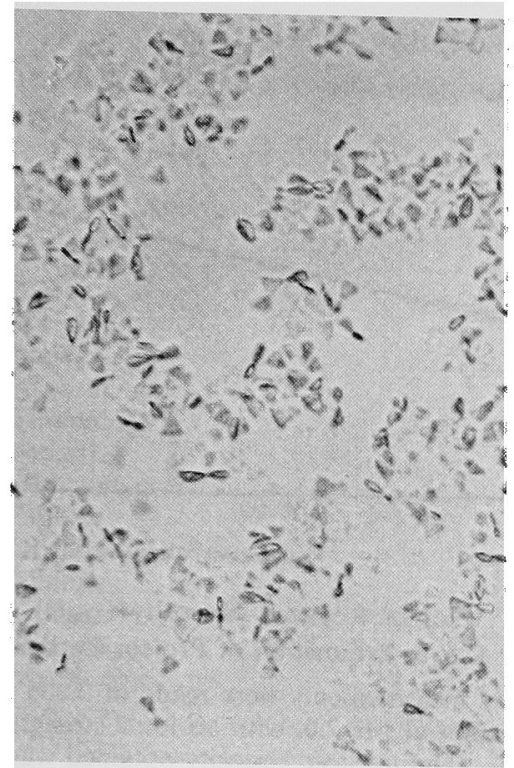

FIG. 1. Microphotograph of Crystalline AcE.

about $40 \%$ of the original activity.

\section{Physical properties of $A c E$}

\section{a. Sedimentation coefficient}

Experiments were done at $34,400 \mathrm{rpm}$ in a standard $12 \mathrm{~mm}, 4^{\circ}$ sector cell. The sedimentation coefficients, $s_{20, \mathrm{w}}$, at various concentrations of AcE protein in phosphate buffer at $\mathrm{pH} 7.0$ of ionic strength 0.2 with sodium chloride, were calculated from the sedimentation patterns, typical one of which was presented in a previous paper." ${ }^{1}$ The sedimentation coefficient were obtained by extrapolating the plot of S versus concentration of the enzyme to zero, and the value of $5.5 \mathrm{~S}$ was obtained. A small variation of sedimentation coefficient was observed in accordance with the solvent employed, that is, $s_{20, \mathrm{w}}^{0}$ was $5.05 \mathrm{~S}$ in acetate buffer at $\mathrm{pH} 5.5$ of ionic strength 0.1 , as shown in Fig. 2.

In the case of pig liver carboxylesterase, ${ }^{14)}$ the dissociation of native form to an active half molecular form occurs between $\mathrm{pH} 5.0$ and 4.0, and the sedimentation coefficients change from $8.12 \mathrm{~S}$ to $4.1 \mathrm{~S}$. In our case, sedimentation coefficient of AcE decreased slightly from $7.2 \mathrm{~S}$ in phosphate buffer at pH 7.0 of ionic strength 0.1 to $5.05 \mathrm{~S}$ in acetate

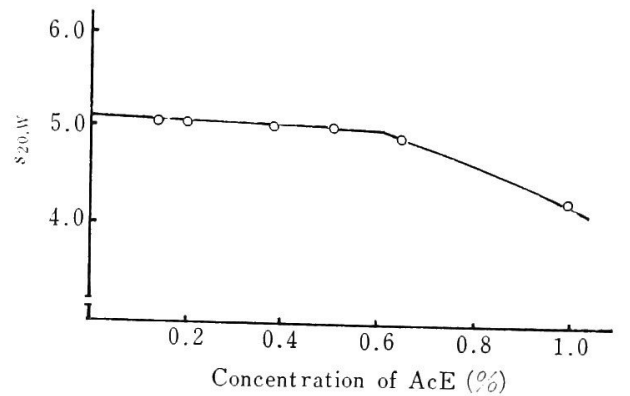

FIG. 2. Plots of Sedimentation Coefficient as a Function of AcE Concentration.

The individual $s_{20 \text {, w }}$ values were obtained from runs in $0.0054 \mathrm{M}$ acetate buffer, $\mathrm{pH} 5.5$, with an ionic strength of 0.1 at $20^{\circ} \mathrm{C}$. The extrapolated value of $s_{20, \mathrm{w}}^{0}$ is $5.05 \mathrm{~S}$.

buffer, at pH 5.5. The change of sedimentation coefficients may be related to the dissociation of native molecule to a half molecule, and this will be investigated under various conditions in further experiments. However, further experiments are required to manifest if this decrease in the sedimentation coefficients would be due to the dissociation of the native enzyme molecule.

\section{b. Molecular weight}

i. Archibald method. Approach to sedimentation equilibrium for the determination of molecular weight by Archibald method was conducted in a $12 \mathrm{~mm}, 4^{\circ}$ sector cell at 13,100 rpm and at $23.5^{\circ} \mathrm{C}$ with 0.2 and $0.98 \%$ enzyme dissolved in the same buffer used for the sedimentation velocity runs. The concentration of original sample was determined in arbitrary units in a $12 \mathrm{~mm}, 4^{\circ}$ sector synthetic boundary cell and average molecular weight at the meniscus was calculated according to the method described by Schachman. ${ }^{2)}$ The molecular weight of AcE in phosphate buffer at pH 7.0 of ionic strength 0.2 was calculated as approximately 78,500 .

ii. Gel-filtration. The molecular weight of AcE was estimated by gel-filtration method with a Sephadex G-200 column. The molecular weight of AcE was estimated to be 78,500 , as presented in Fig. 3. From the results of molecular weight estimation on 


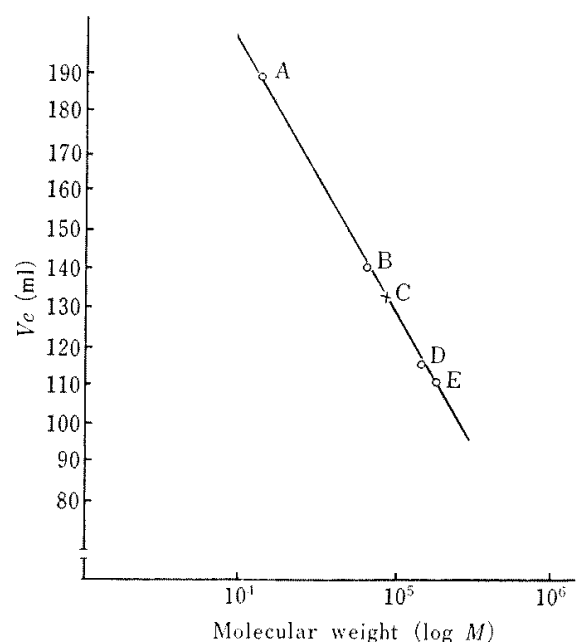

FIG. 3. Estimation of Molecular Weight of Crystalline AcE with Sephadex Gel Filtration.

The column $(2.8 \times 58 \mathrm{~cm})$ of Sephadex G-200 was equilibrated with $0.75 \mathrm{M} \mathrm{NaCl}$ containing $0.025 \mathrm{M}$ $\mathrm{MgCl}_{2}$. A, cytochrome $c$ (horse); $\mathrm{B}$, serum albumin (bovine); $\mathrm{C}$, acetylesterase; $\mathrm{D}$, lactate dehydrogenase; E, $\gamma$-globulin.

equilibrium sedimentation and gel-filtration, AcE protein apparently has a molecular weight of 78,500 . Recently, the molecular weight of pig liver esterase ${ }^{14}$ has been shown to be $85,000 \sim 90,000$ and that of rat liver esterase, ${ }^{15)}$ which has a trimeric structure, 177,000. The molecular weight of $\mathrm{AcE}$ is close to that of pig liver esterase.

\section{c. Intrinsic viscosity}

After determining the outflow times required by the buffer and protein solutions, the relative viscosity was calculated by the method described by Kuroiwa et al. ${ }^{16 !}$ As shown in Fig. 4, the reduced viscosity was expressed as a function of protein concentration, and the intrinsic viscosity $([\eta])$ was obtained as 0.0277 $\mathrm{dl} / \mathrm{g}$ from the figure.

\section{d. Partial specific volume}

Duplicate determination of partial specific volume of AcE yielded a value of 0.724 . The partial specific volume 0.726 , evaluated from the amino acid composition, was slightly higher than the value determined by experiment.

The frictional ratio $\left(f / f_{0}\right)$ was calculated to be 1.28 from sedimentation and molecular weight.

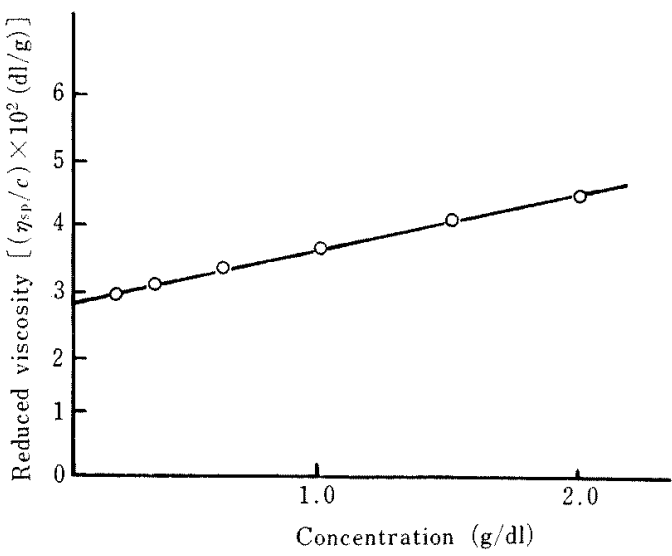

FIG. 4. Plot of Reduced Viscosity $\left(\eta_{\mathrm{sp}} / c\right)$ of Crystalline AcE as a Function of Protein Concentration.

Viscosity measurements were made in $0.005 \mathrm{M}$ phosphate buffer at $\mathrm{pH} 7.0$, with an ionic strength of 0.2 at $20^{\circ} \mathrm{C}$. The intrinsic viscosity obtained was 0.0277 $\mathrm{dl} / \mathrm{g}$.

\section{e. Isoelectric point}

With $1.5 \mathrm{ml}$ of enzyme solution, containing $25 \mathrm{mg}$ of protein, an experiment of isoelectric focusing was performed. After focusing for $44 \mathrm{hr}$ with a constant potential of 800 volts and an initial current of $4.8 \mathrm{~mA}$, the contents of the column were cut into $3 \mathrm{ml}$ fractions. The amounts of protein in the fractions were estimated by measuring absorbancy at $280 \mathrm{~nm}$. On the basis of isoelectric focusing, $\mathrm{AcE}$ appeared to be a homogeneous substance having a pI at 3.95 (Fig. 5).

\section{f. Optical rotatory dispersion measurement}

The parameters of $a_{0}$ and $b_{0}$ were calculated from the Moffitt-Yang equation using $212 \mathrm{~nm}$ as $\lambda_{0}$. The $a_{0}$ value was -110 and $b_{0}$ value -75 . Figure 6 shows ORD spectrum for the 195 to $270 \mathrm{~nm}$ region. AcE protein showed the negative Cotton effect at $232 \mathrm{~nm}$ with the value of 2200. Shoulder also appeared at 210 to $215 \mathrm{~nm}$, suggesting the presence of the $a$-helix. AcE protein contains $11 \%$ of the $\alpha$-helix structure judging from the $b_{0}$ value.

\section{Amino acid composition}

Amino acid composition of AcE of Sclerotinia fungus is presented in Table I. When 
Table 1. Amino Acid Composition of Sclerotimia Fungal Acetrlesterase

The values without any signs were the average of analyses of four hydrolysates obtained from $18,24,48$, and $72 \mathrm{hr}$ hydrolysates.

\begin{tabular}{|c|c|c|c|}
\hline \multirow{2}{*}{ Amino acid } & \multirow{2}{*}{$\frac{\text { Amino acid residues }}{(\%)}$} & \multicolumn{2}{|c|}{ No. of amino acid residues ${ }^{a}$} \\
\hline & & Calculated & Integer \\
\hline Lysine & 2.08 & 12.3 & 12 \\
\hline Histidine & 2.56 & 14.2 & 14 \\
\hline Arginine & 3.84 & 18.4 & 18 \\
\hline Aspartic acid & 11.6 & 76.3 & 76 \\
\hline Threonine $^{b}$ & 7.06 & 51.7 & 52 \\
\hline Serine $^{b}$, & 6.90 & 61.7 & 62 \\
\hline Glutamic acid & 10.25 & 60.2 & 60 \\
\hline Proline & 6.17 & 48.2 & 48 \\
\hline Glycine & 6.76 & 90.0 & 90 \\
\hline Alanine & 5.32 & 57.0 & 57 \\
\hline Cysteine & 0.56 & 4.0 & 4 \\
\hline Valine ${ }^{\circ}$ & 4.69 & 36.1 & 36 \\
\hline Methionine & 1.36 & 7.85 & 8 \\
\hline Isoleucine $^{c}$ & 5.53 & 37.0 & 37 \\
\hline Leucine & 6.35 & 42.3 & 42 \\
\hline Tyrosine & 8.21 & 38.4 & 38 \\
\hline Phenylalanine & 6.72 & 34.7 & 35 \\
\hline Tryptophan ${ }^{d ?}$ & 4.65 & 19.4 & 19 \\
\hline Total & 100.61 & & 708 \\
\hline $\mathrm{NH}_{3}{ }^{e l}$ & $(1.03)$ & (49) & (49) \\
\hline
\end{tabular}

a) Based on a molecular weight of 78,500 and $3.34 \%$ of hexose content.

b) Values extrapolated to zero hydrolysis time.

c) Maximum values were adopted.

d) Value determined spectrometrically.

e) Determined only in the $18 \mathrm{hr}$ hydrolysate.

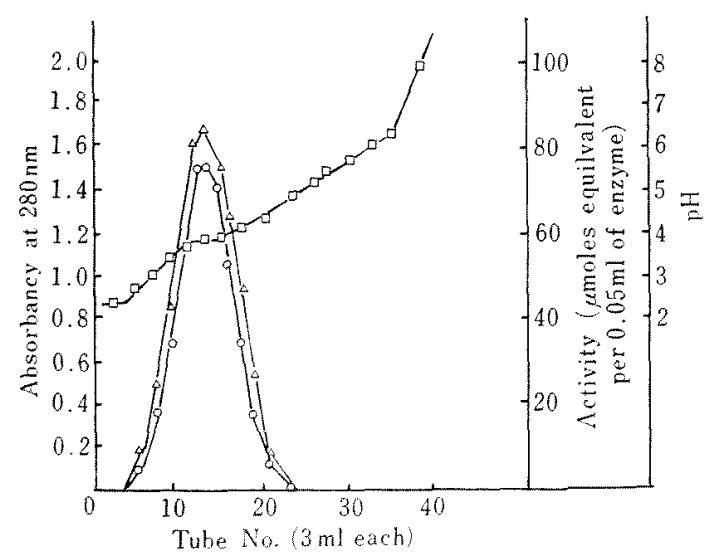

FIG. 5. Isoelectric Focusing Pattern of Purified AcE.

Purified AcE, $25 \mathrm{mg}$, was used. Electrophoresis was carried out with an ampholyte of $\mathrm{pH}$ range from 3 to 6 with a current of $4.8 \mathrm{~mA}$ for $48 \mathrm{hr}$ at $4^{\circ} \mathrm{C}$. The column volume was $110 \mathrm{ml}$.

$\triangle \rightarrow \triangle$, protein, absorbancy at $280 \mathrm{~nm} ; 0-0$, activity; $\square-\square$, pH curve. the molar ratio of each amino acid was calculated on the assumption that the content of arginine was 18 moles per mole of $\mathrm{AcE}$, the total number of amino acid residue became 708 , and the molecular weight of the protein portion was calculated to be 76,500. AcE protein contained much more acidic amino acid residues than basic ones and also more hydroxyl and carboxyl groups of amino acid residues. Titrations of the sulfhydryl group in AcE were performed with $\mathrm{PCMB}$ at a specifically set concentration $\left(4.12 \times 10^{-8}\right.$ mole $)$ and a varying concentration of $\mathrm{PCMB}$ in the presence of $8 \mathrm{M}$ urea in $10 \mathrm{ml}$ of $0.1 \mathrm{M}$ phosphate buffer at pH 7.0 at $25^{\circ} \mathrm{C}$. The changes in absorbancy of the reaction mixtures at $250 \mathrm{~nm}$, corrected for the absorbancy of PCMB in the same solvent in the absence of $A c E$, were measured at time intervals. The reaction for $16 \mathrm{hr}$ or more gave the maximum 


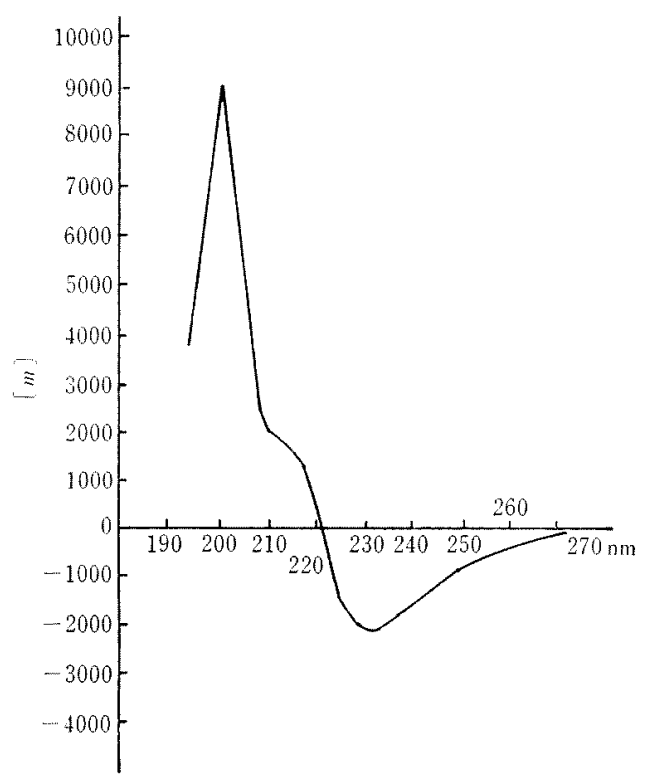

FrG. 6. Optical Rotatory Dispersion Spectrum of $\mathrm{AcE}$ in Phosphate Buffer, $\mathrm{pH} 7.0$.

Enzyme concentration, $2.48 \mathrm{mg}$ per milliliter, light path, $0.1 \mathrm{~mm}$; full scale, 0.2 .

value, 4 moles per mole AcE, as shown in Fig. 7. After performic acid oxidation, four moles of cysteic acid were detected by amino acid analysis. Thus, the enzyme was assumed to contain 4 moles of cysteine which can react with PCMB per mole of the enzyme. The estimation of extinction at $280 \mathrm{~nm}$ from the tyrosine, phenylalanine and tryptophan con-

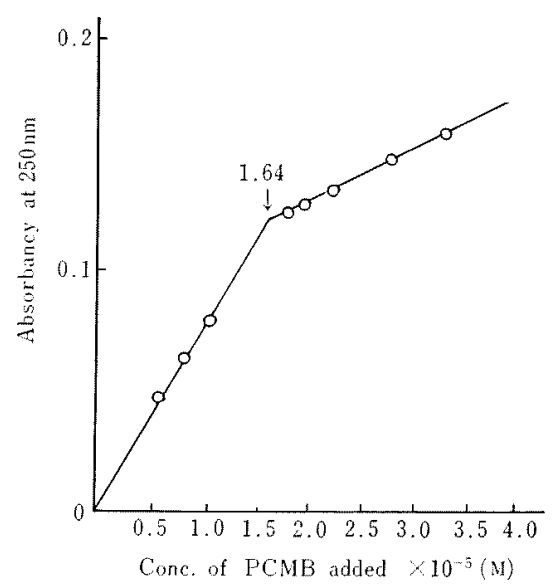

Fic. 7. Spectrophotometric Titration of $8 \mathrm{M}$ Urea Denatured AcE with PCMB. tents was carried out according to the method of Hsiu, Fisher and Stein $^{17}$ yielding a value of 24.7, which was slightly higher than the experimentally obtained 23.24. Ultraviolet absorption spectrum of AcE is shown in Fig. 8.

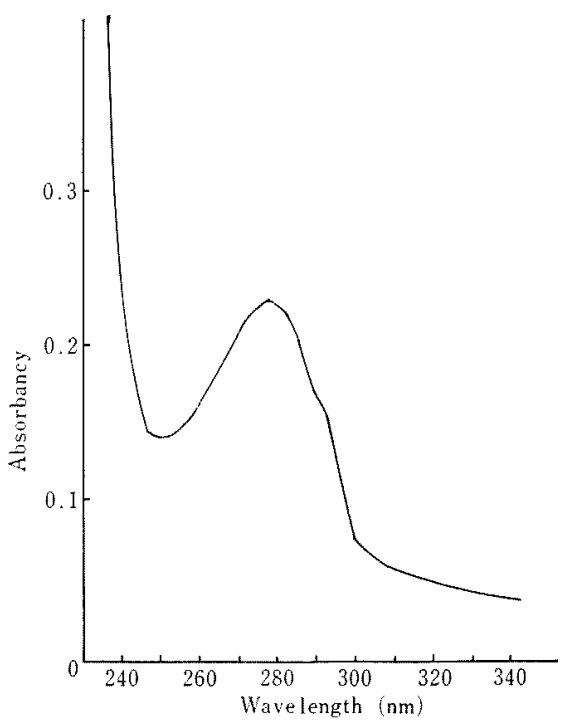

Fig. 8. Ultraviolet Absorption Spectrum of Crystalline AcE.

The protein $(0.0996 \mathrm{mg})$ was dissolved in $1 \mathrm{ml}$ of $0.1 \mathrm{M}$ acetate buffer at $\mathrm{pH} 5.5$. The absorption spectrum was recorded on a Shimazu recording spectrophotometer model UV 200.

\section{4. $N$-terminal and $C$-terminal analyses}

The reaction with 2-fluorodinitrobenzene was performed in the presence of $0.1 \mathrm{M}$ sodium bicarbonate at $40^{\circ} \mathrm{C}$. The reaction product was successively washed with $\mathrm{HCl}$, acetone and ether. The dinitrophenyl (DNP-) protein (about $10 \mathrm{mg}$ ) was hydrolyzed in an evacuated sealed tube with $6 \mathrm{~N} \mathrm{HCl}$ at $110^{\circ} \mathrm{C}$ for $12 \mathrm{hr}$. DNP-amino acid was extracted with ether from the hydrolyzate and chromatographed on silica gel thin-layer plate. Two-dimentional chromatography was performed with a toluenepyridine-ethylenchlorohydrin- $0.8 \mathrm{~N} \quad \mathrm{NH}_{4} \mathrm{OH}$ $(100: 30: 60: 60, \mathrm{v} / \mathrm{v})$ system in the first direction and a chloroform-methanol-glacial acetic acid $(95: 5: 1, \mathrm{v} / \mathrm{v})$ system in the second direction. N-terminal analysis showed that the N-terminal of the enzyme was threonine. No other DNP-amino acid was detected. 
For the confirmation of DNP-threonine, hydrolysis by ammonium hydroxide was applied to the DNP-amino acid fraction and the regenerated amino acid was also identified as threonine by amino acid analysis.

Determination of N-terminal amino acid of AcE by applying bacterial aminopeptidase gave the same result. After 120 min of reaction with 10 nmoles of AcE, 9 nmoles of threonine was first split off, then 4 nmoles of serine and valine and 4 nmoles of phenylalanine, in that order. From these results, threonine was concluded to be the $\mathrm{N}$-terminal amino acid of AcE protein.

The C-terminal amino acid of AcE was liberated by carboxypeptidase A and Y. After $2.5 \mathrm{hr}$ of reaction, 5 nmoles of serine, 3 nmoles of tyrosine and 3 nmoles of aspartic acid were liberated by 0.5 units of carboxypeptidase A from 30 nmoles of AcE protein, but the liberation of serine did not proceed very rapidly. In order to ascertain the C-terminal amino acid of $\mathrm{AcE}$, the rates of release of amino acids by carboxypeptidase $\mathrm{Y}$ were followed quantitatively. The results are summarized in Fig. 9. For the first $20 \mathrm{~min}$, five amino acids were liberated rapidly; i.e., serine and tyrosine appeared, accompanied by further release of aspartic acid, threonine and glycine. The control experiments which contained only carboxypeptidase $\mathrm{Y}$ yielded no detectable amino acids. The C-terminal amino acid of AcE protein was concluded to be serine.

\section{Detection of carbohydrate}

Total content of carbohydrate in the enzyme was found to be 3.34 percent by the phenolsulfuric acid method and also by the anthrone method using glucose as a standard. The molar content in AcE protein molecule was calculated to be 16 moles being assumed as glucose. No glucosamine and galactosamine was detected on the amino acid analyzer. Three or more components other than glucose in the carbohydrate moiety were detected on TLC. The carbohydrates in AcE protein will be investigated in further experiments.

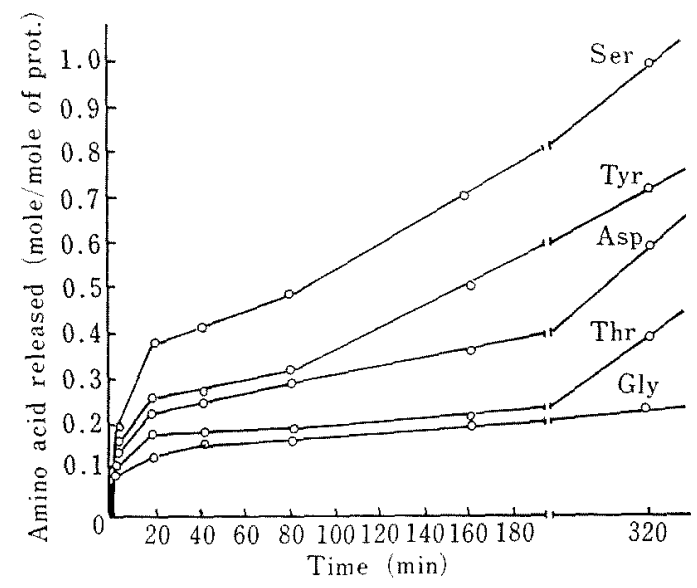

FIG. 9. Time-Course of the Release of Amino Acids from AcE Protein by Carboxypeptidase $\mathrm{Y}$.

AcE protein, $3.75 \mathrm{mg}$, was dissolved in $200 \mu 1$ of $0.1 \mathrm{M}$ pyridine-acetate buffer at $\mathrm{pH}$ 5.5. Carboxypeptidase $\mathrm{Y}, 15 \mu$, containing about $15 \mu \mathrm{g}$ was added to the reaction mixture. After $0,20,40,80,160$ and $320 \mathrm{~min}$, each $20 \mu 1$ of sample was withdrawn and mixed with $20 \mu$ of $10 \%$ acetic acid. After being dried under $\mathrm{N}_{2}$ gas flow, the material was dissolved in $50 \mu$ l of citrate buffer, $\mathrm{pH} 2.2$, and applied to an amino acid analyzer after the removal of any insoluble material by centrifugation.

Acknowledgement. The author wishes to express his sincere thanks to Professor Y. Satomura of Osaka City University for his discussions and encouragement on this work. Thanks are also due to Drs. S. Okada and K. Hiyama of Osaka Municipal Technical Research Institute for their guidance on the ORD measurements, to Dr. K. Kakiuchi of Osaka University for his guidance on the ultracentrifugal analysis, and to Dr. N. Minamiura of Osaka City University for his kindly supply of bacterial aminopeptidase.

\section{REFERENCES}

1) S. Oi and Y. Satomura, Agr. Biol. Chem., 31, 561 (1967).

2) H. K. Schachman, "Methods in Enzymology," IV, Academic Press Inc., New York, 1957, p. 32.

3) T. Svedberg and D. K. Pederson, "The Ultracentrifuge," Claredon Press, Oxford, 1940, p. 445.

4) P. Andrews, Biochem. J., 91, 222 (1964).

5) T. W. Goodwin and R. A. Morton, ibid., 40, 628 (1946).

6) P. D. Boyer, J. Amer. Chem. Soc., 76, 4331 (1954).

7) C. H. W. Hirs, "Methods in Enzymology," XI, Academic Press Inc., New York, 1967, p. 59.

8) M. Dubois, K. A. Gills, J. K. Hamilton, P. A. Rebers and F. Smith, Anal. Chem., 28, 350 (1956). 
9) T. A. Scott and E. H. Melvin, Anal. Chem., 25, 13) W. Moffitt and J. T. Yang, Proc. Natl. Acad. 1656 (1953).

10) H. Fraenkel-Conrat, J. I. Harris and A. L. Levy, "Methods of Biochemical Analysis," Vol. 2, Academic Press Inc., New York, 1955, p. 359.

11) N. Minamiura, Y. Matsumura, T. Yamamoto and J. Fukumoto, Agr. Biol. Chem., 33, 653 (1969). Sci. U.S., 42, 596 (1956).

14) D. L. Barker and W. P. Jenks, Biochemistry, 8, 3879 (1969).

15) H. Hollandt, Eur. J. Biochem., 36, 120 (1973).

16) I. Kuroiwa et al., "Jikken Kagaku Koza," Vol. 8, ed. by A. Kodera, Maruzen Co., Ltd., 1956, p. 135 (in Japanese).

12) R. Hayashi, S. Moore and W. H. Stein, J. Biol. 17) J. Hsiu, E. H. Fisher and E. A. Stein, BiochemiChem., 248, 2296 (1973). stry, 3, 61 (1964). 